\title{
Quantitative Estimation of Smash Feeling for Various \\ Ping-Pong Balls
}

\author{
by
}

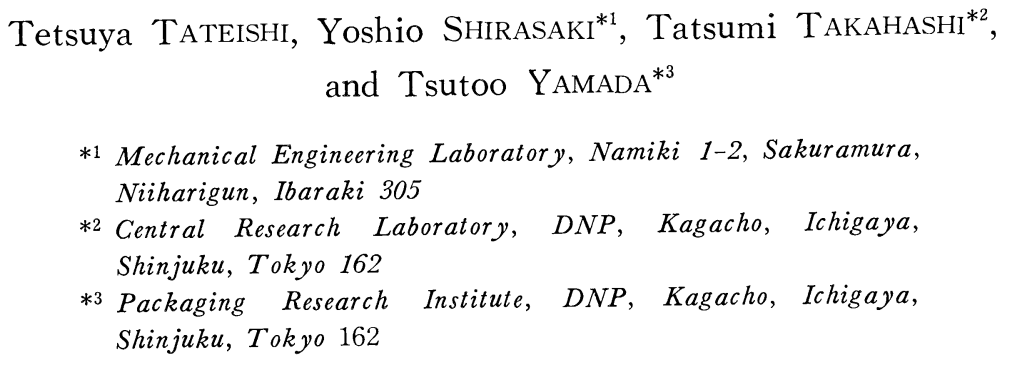

In order to disclose the smash feeling of ping-pong balls, regional and directional differences of dynamic compression stiffness of a ball were investigated for conventional celluloid balls and newly designed plastic balls by a viscoelastic spectrometer.

In the conventional celluloid balls, the dynamic compression stiffness of the equatorial (connected) part of the ball at $15 \mathrm{~Hz}$ averaged $6.5 \times 10^{7} \mathrm{dyne} / \mathrm{cm}$, and the phase-lag was about 4 degrees. The equatorial measurements gave 1.5 times the compression stiffness of the polar regions and about the same degrees of phase-lag.

On the other hand, plastic balls generally had increased values of dynamic stiffness at the polar part and decreased values of stiffness at the equatorial part, and the plastic balls also indicated strain-rate sensitive mechanical behavior. These facts indicate that the newly designed plastic ball tends to be hard and metal-like when it is smashed in play.

\section{卓球ボールの打球感に関する研究}

\author{
立石 哲也 - 白崎 芳夫 ${ }^{* 1} \cdot$ 高橋 達見 ${ }^{* 2} \cdot$ 山田 務夫 ${ }^{* 3}$
}

(原稿受理 : 1981年 1 月23日)

\section{1. はじめに}

現在使用されている競技用卓球ボールの大多数はセルロイド製 であるが，セルロイド原料の入手難，火災防止規制による保存及 び加工時に扣ける取扱い、制限, 材料の品質管理と多量生産の困難 な点等を考虑して, 徐々にプラスチックボールに代替される客観 情勢にある。しかしながら，永年慣れ親しんだセルロイドボール の打球感をプラスチックで実現させるためには, 材料の選択と処

*1 機械技術研究所 $\mathbf{T} 305$ 茨城県新治郡桜村並木 $1-2$

*2 大日本印刷(株)中央研究所 $=162$ 東京都新宿区市谷加賀町

*3 大日本印刷(株)包装研究所 同上
理及び成形方法等で多くの打球感制御因子を究明しなければなら ない、現状では, 試作したボールを卓球の一流選手に試し打ちさ せ，その結果から適当な材料や成形方法を試行錯誤的に決定する という非能率的な官能検査にたよらざるをえない，セルロイド球 の場合でも, 静的な硬さ試験はもとより, 打球感評価に必要な動 的な粘弾性試験はほとんど行われていないのが現状である.

熱可塑性樹脂を射出成形して卓球ボールを作る場合, 樹脂が温 度及び変形速度敏感性であれば, 室温と打撃速度によってボール の特性が著しく变化する。ボールのレオロジー的性質の変化を最 小限に扣さえなければ, ボールのコントロールが困難になり, 競 
技が環境条件によって左右されることになる．ささらに樹脂素材の 流れによる異方性やボールのつなぎの部分及び樹脂注入口跡等の 影響によるボール特動性の非均一性も極力抑える必要がある。

プラスチックボール開発の第一歩として，打球感の定量的評価 因子決定のため, ボールの粘弾性を測定し打球感との相関性を検 討した.

\section{2. 試料及び実験方法}

試験に用いたセルロイドボールは，市販されている日本製ボー ル 4 種 $(1,2,3,4)$ であり，プラスチックボールは英国製 ABS 樹脂ボールと試作球（セルロースプロピオネート2種）で ある. 七ルロイドボールの一般的な製造工程は，シート打抜き $\rightarrow$ 絞り成形 $\rightarrow$ 半球外周カット $\rightarrow$ 半球合せ, 接着 $\rightarrow$ 乾燥 $\left(30^{\circ} \mathrm{C}, 1\right.$ 力

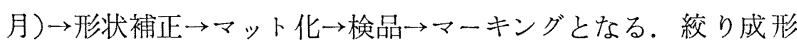
の工程に怙いて, 中国製ボールは古来からの湯絞め法, 日本製ボ 一ルは乾熱式（熱風成形）で半球を絞り成形しているが，その詳 細は明らかにされていない。

プラスチックボールの試作には，型締圧 50 ton の射出成形機 を使用した。セルロースプロピオネート系樹脂の射出成形時の配 向を除去する目的で，射出成形された半球をオーブン中にて加熱 し熱処理した. セルロイドボール, プラスチックボールともITTF 規格に合格したものを用いた。すなわち，重量 $(W): 2.40 \mathrm{~g} \leqq W$ $\leqq 2.53 \mathrm{~g}$, 外径 $(D): 37.2 \mathrm{~mm} \leqq D \leqq 38.2 \mathrm{~mm}$, 反発力 $(H): 23.5 \mathrm{~cm}$ $\leqq H \leqq 25.5 \mathrm{~cm}$ ( $30.5 \mathrm{~cm}$ の高さから鉄ブロック上への落下時).

卓球ボールの粘弾性測定には非共振, 強制振動型の粘弾性試験 機を用い,ボールの固定には Fig. 1 亿示す特殊な治具を使用し た. ボールの力学的異方性を明らかにするために，ボールの子午 線上 $0^{\circ} \sim 180^{\circ}$ まで $30^{\circ}$ 牤き測定点を定めた (Fig. 2). 測定周 波数は 1 100 Hz, 測定温度は $-120^{\circ} \mathrm{C} \sim+120^{\circ} \mathrm{C}$ で, 異方性の試 験はすべて室温 $23^{\circ} \mathrm{C}$ 統一して行った。 すずボールに $300 \mathrm{~g}$ の静 的荷重を負荷した後， $\pm 300 \mathrm{~g}$ の振動荷重を重畳した．実際の卓 球ボールとラケットとの接触時間は $1 / 1000$ 秒程度である。した がって, 室温に扣いて少くとも $1000 \mathrm{~Hz}$ 程度の振動数で実験を 行う必要があるが，これを低温における同じひずみ速度を与える

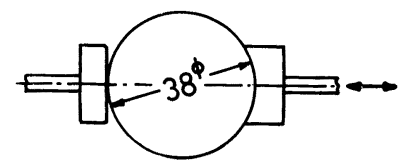

Fig. 1 Holder for a ping-pong ball with the spherical and plane indenters.

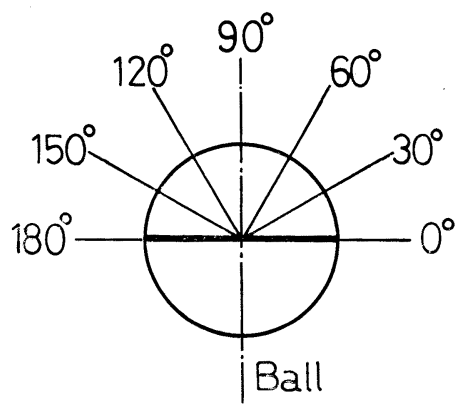

Fig. 2 Polar coordinate of the ping-pong ball and sites of viscoelastic measurement.
周波数に換算して，そのときの動特性をもって打球時の力学的挙 動を類推した。

卓球ボールは薄い球殼構造をしており, 比較的高い室温やスマ ッシュ時には非弾性の大変形を起こすので簡単な弾性解での説明 は不可能である，そこで球殼の変形に対する荷重応答をボールの 動的剛性と定義し, これによってボールの動特性を代表させる.

$$
E=E_{1}+i E_{2}=\frac{\Delta F}{\Delta l}(\cos \delta+i \sin \delta), \tan \delta=E_{2} / E_{1}
$$

ここで, $\Delta F$ は荷重振幅, $\Delta l$ は変位振幅, $\Delta F / \Delta l$ は㴊性 (stiffness) である.

\section{3. 結果と考 察}

Fig. 3 はセルロイドボール, ABS 樹脂ボール (英国製) 拈よ び熱可塑性樹脂（セルロースプロピオネート）を用いた試作ボー ル (CP) の動的剛性の温度依存性を示す. 荷重方向は接合部（赤 道）と $45^{\circ}$ をなす位置をとり，周波数は $30 \mathrm{~Hz}$ である. 各球と も球殼であり，また接合部を有しているため，単純に時間一温度 換算則は適用できない。セルロイドボールは他の 2 球に比較して 低温域（ $-120^{\circ} \mathrm{C}$ 以下）飞分散を持っていて, $-100^{\circ} \mathrm{C} か ら+80^{\circ} \mathrm{C}$ の温度領域で剛性の变化は少ない，これは室温を中心とする広い 温度領域と広いひずみ速度域に対して安定した動的剛性を保持し ていることを意味して扔り，打球のコントロールに環境条件があ まり関与しないことを示す。したがって，セルロイドは卓球ボー ルの素材としてすぐれて和り, 合目的的であるがセルロイドボー 儿誕生当時，これ以外の素材は考えられなかったのであるから， 偶然がもたらした好結果といえる。

ABS ボールはー $70^{\circ}$ 付近に遷移領域があり，剛性は急激に上昇 する．これは大きなひずみ速度に対して弾性率が増加することを 意味して扣り，ABS ボールがスマッシュ時に金属的な打球感を 有することの原因と考光られる。熱可塑性樹脂試作球 (CP) は ABS ボールと同様な温度特性があり，高ひずみ速度域で硬質な 感じを与兄る。

Fig. 4はセルロイドボールと試作ボールの極拉よび赤道に和け

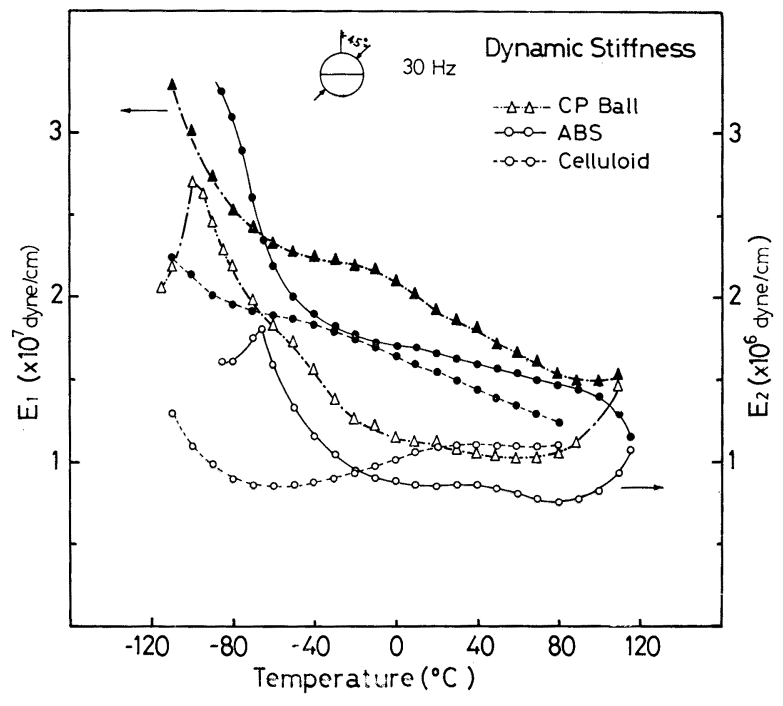

Fig. 3. Temperature-dependence of the dynamic stiffness of ping-pong balls. 


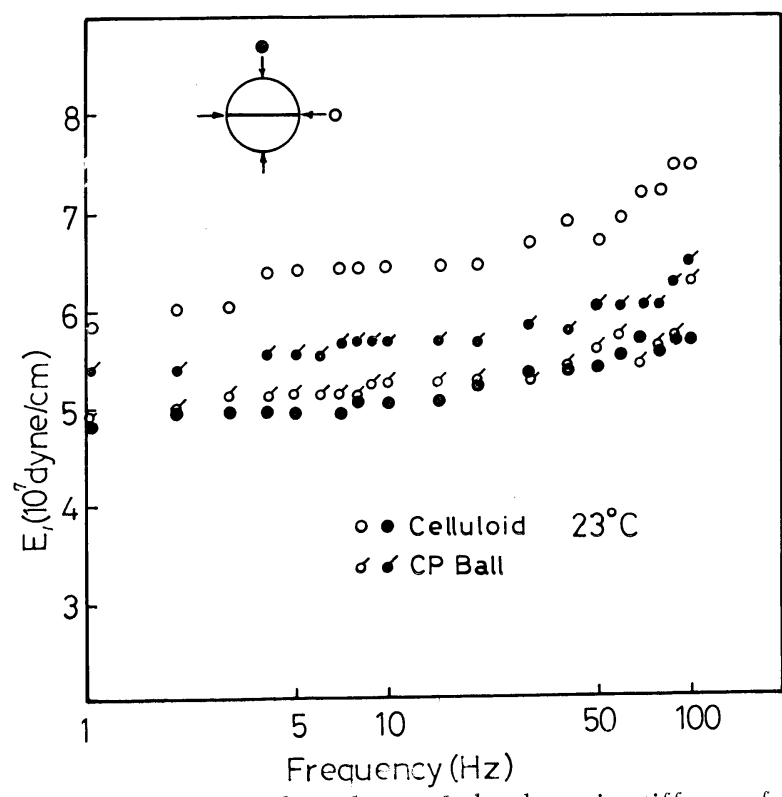

Fig. 4 Frequency-dependence of the dynamic stiffness of the celluloid ball at the polar and equatorial part.

る動的剛性の周波数依存性を示す。セルロイドボールの場合は赤 道面の接着部分の影響が強く, 接着の補強がない極の部分との差 は動的剛性で約30\%ある。これはボールとラケットの衝突位置に よっては, ボールの反発係数に $30 \%$ 程度の差があることを意味し て扮り，ボールのコントロールを困難にする原因となりうる。こ れに対し試作ボールの場合, 赤道より極の方向で動的剛性が高く なって招り，射出成形による樹脂の流れが動的剛性に異方性を与 えていることを示す。いずれにせよ動的剛性の異方性はボールの 性能低下を意味して扣り,ボール製造上極力避けなければならな い.

セルロイドボールの力学的異方性をより詳細に調べると Fig. 5 のようになる. 図の上半分は動的剛性, 下半分は位相差の方位依 存性を示す，位相差は方位によってほとんど変化しないが，動的

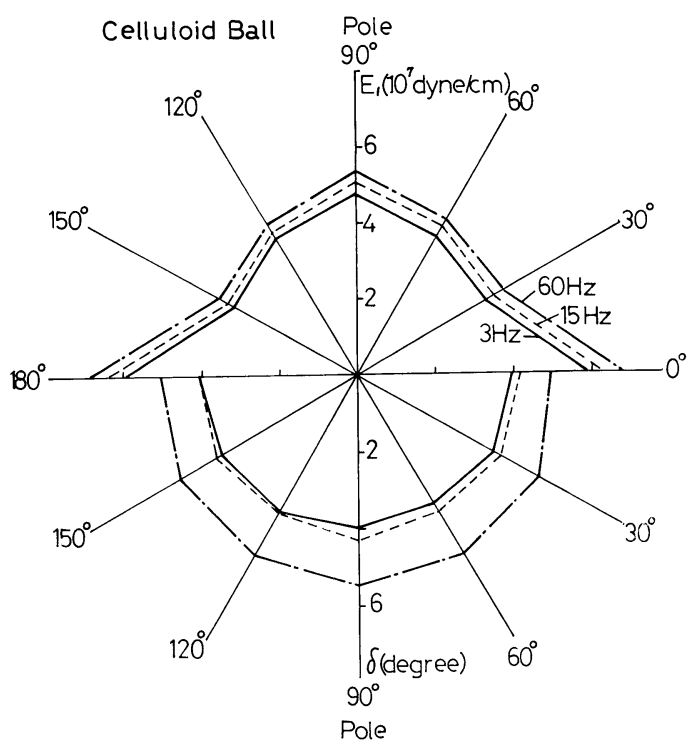

Fig. 5 Directional differences of the dynamic stiffness and the phaselag of the celluloid ball.

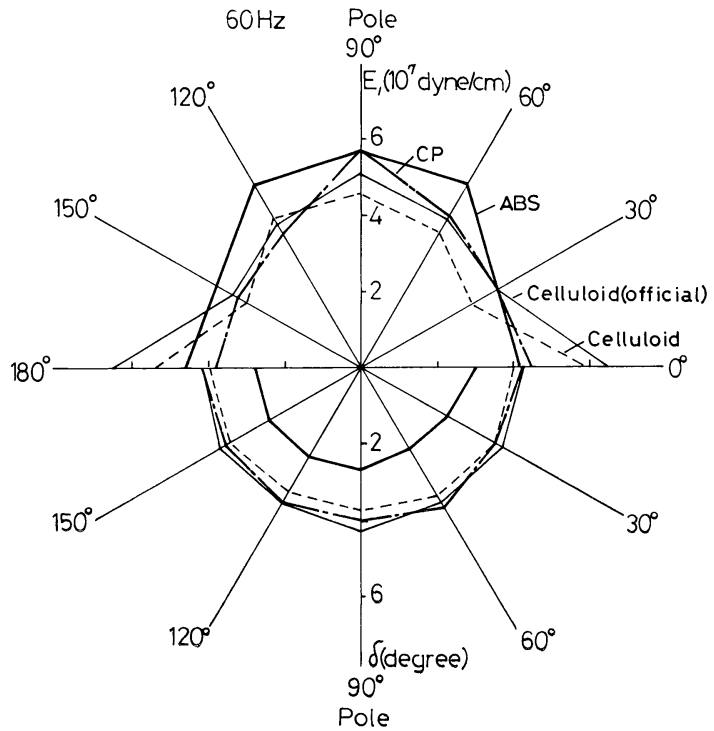

Fig. 6 Directional differences of the dynamic stiffness and the phaselag of various ping-pong balls.

剛性は $0^{\circ}$ 方向でとくに增大している。セルロイドには材質的な 異方性はほとんど存在しないが，接着による強化という構造的な 要因が強く影響していることは明らかである。

一方，セルロイドボール（日本製 2 社）とプラスチックボール (ABS 樹脂, $\mathrm{CP}$ 樹脂) の $60 \mathrm{~Hz}$ 飞扔ける動的剛性抢よび位相差 の異方性を比較すると Fig. 6 のよ5になる。 セルロイドボール はいずれも接着部での異方性があるのに対し，プラスチックボー ルはいずれも極方向に剛性の最大值がある. 球の異方性が材質と いうより製造方法によって決定されるという現状では，異方性の

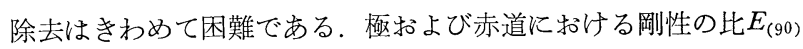
$/ E_{(0)}$ を球の異方性の目安とすると, 七ルロイドボールでは 2 種 共に0.78であるのに対し, ABS 樹脂ボールは1.30, 試作ボール (CP) は1.25となる. 以上の結果から強化方向が $90^{\circ}$ 異なるとは いえ，異方性の度合は大差ないことが判明した。

次に卓球ボールの動的剛性の構造力学的な意味について考察し よ5，簡単化のために厚さ $h$, 半径 $R$ の球款に集中荷重 $f$ が作用 したとき, 変位が十分小さいと仮定すると, 荷重点に拈ける最大 変位 $は^{1)}$,

$$
\zeta \propto \frac{f R}{E_{0} h^{2}}
$$

で与えられる (Fig. 7). ここで， $E_{0}$ は球款素材の弾性率である. 卓球ボールの粘弾性試験では, ボールに一定荷重を負荷し,さらに

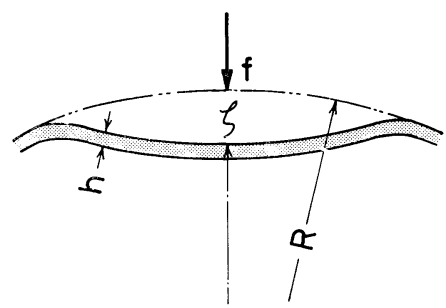

Fig. 7 Deformation of spherical shell, $\zeta:$ deformation, $f$ : concentrated load, $R$ : radius of spherical shell, $h$ : thickness of spherical shell. 
振動荷重を重畳して作用させるので, クリープ変形と振動応答が 同時に生ずる．材料のクリープ関数 $D$ を $D(t)=D_{0}+D_{1}\left(1-e^{t / \tau}\right)$ とすると, 慣性項が無視できる場合には球殸の弾性解(1) と対応原 理によって, 粘弾性球殼の変形らは次式で表される2).

$$
\zeta(t) \propto \frac{R f_{0}}{h^{2}}\left[D(0) \sin \omega t+\int_{0}^{t} \sin \omega t \frac{d D\left(t-t^{\prime}\right)}{d\left(t-t^{\prime}\right)} d t^{\prime}\right]
$$

ただし,クリープ変形については, 荷重 $f(t)=I(t)$ (単位応答関 数), 振動荷重は $f(t)=f_{0} \sin \omega t$ とする.

式(2)にDを代入すると，

$$
\begin{aligned}
\zeta(t) & \propto \frac{R f_{0}}{h^{2}}\left\{D_{0} \sin \omega t\right. \\
+ & \left.\frac{D_{1} \tau}{1+(\tau \omega)^{2}} e^{-t / \tau}\left[e^{-t / \tau}\left(\frac{1}{\tau} \sin \omega t-\omega \cos \omega t\right)+\omega\right]\right\}(3)
\end{aligned}
$$

遅延時間 てが観測時間に比べて十分大きいとき $(\tau \gg t)$, 式(3)を展 開して, $1 / \tau^{2}$ 以上の次数の項を省略すると，

$$
\zeta(t)=\frac{R f_{0}}{h^{2}}\left[\sqrt{D_{0}^{2}+\left(D_{1} / \omega \tau\right)^{2}} \sin (\omega t-\delta)+\frac{D_{1}}{\omega \tau}\right], \tau \gg t \quad(4)
$$

ここで, 位相差 $\delta$ は

$$
\delta=\tan ^{-1}\left(D_{1} / D_{0} \omega \tau\right)
$$

式(5)から明らかなように, 卓球ボール素材のてが小さいと, ボー ルの見かけ上の $\delta$ は大きい. 式(4)よりボールの見かけ上の動的剛 性は,

$$
E=\frac{f_{0}}{\zeta} \propto \frac{h^{2}}{R}\left[D_{0}^{2}+\left(D_{1} / \omega \tau\right)^{2}\right]^{-1 / 2}
$$

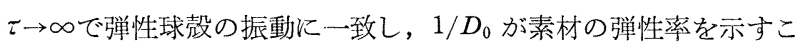
とになる。このようにボールの動的剛性は素材のクリープ特性か らある程度類推することができる。

卓球ボールの動的剛性を支配する構造因子は，ボールの半径 $(R)$ と厚さ $(h)$ である.ところが規格によって，ボールの重量は $2.40 \leqq W \leqq 2.53$, 半径 $(R)$ は $1.86 \leqq R \leqq 1.91$ という制限をうける ので, ボールの素材の密度を $\rho$ とすると,

$$
5.24 \times 10^{-2} \mathrm{~g} / \mathrm{cm}^{2} \leqq h \rho \leqq 5.82 \times 10^{-2} \mathrm{~g} / \mathrm{cm}^{2}
$$

$h \rho=k$ と打くと,ボールの動的剛性は

$$
E \propto \frac{k^{2}}{R \rho^{2}}\left[D_{0}^{2}+\left(D_{1} / \omega \tau\right)^{2}\right]^{-1 / 2}
$$

式(8)より, 素材の弾性率が同じなら, ボールの見かけ上の動的剛 性は素材の密度の 2 乘に反比例して減少する。これは卓球ボール 素材の選定に対し一つの目安を示す.

ゴルフボールの場合にも大きさに関する規格はあるが，反発力， 飛距離に特別の制限はない. したがって, よく飛ぶボールの開発 に精力が注がれる。それに対し卓球ボールの場合, 微妙なボール コントロールが要求されるので, 現在使用されている公式ボール の打球感に近いボールを開発しなければならない，そこで, 測定 した各種卓球ボールの動特性を $E_{1}-E_{2}$ 座標面にプロットして, 大ざっぱなボール開発指針を求めることにする。 セルロイド製の 公式ボールの測定結果を中心にして，その占める領域を $E_{1}$ と $\delta$ $=\tan ^{-1}\left(E_{2} / E_{1}\right)$ で決定すると, この領域 (Fig. 8 のハッチング した部分）がボールの設計目標となる.

この領域の中心に新しい座標を設定すると, 第 1 象限はボール が硬く球離れが悪い，第 2 象限は軟かくかつねばっこい，第 3 象

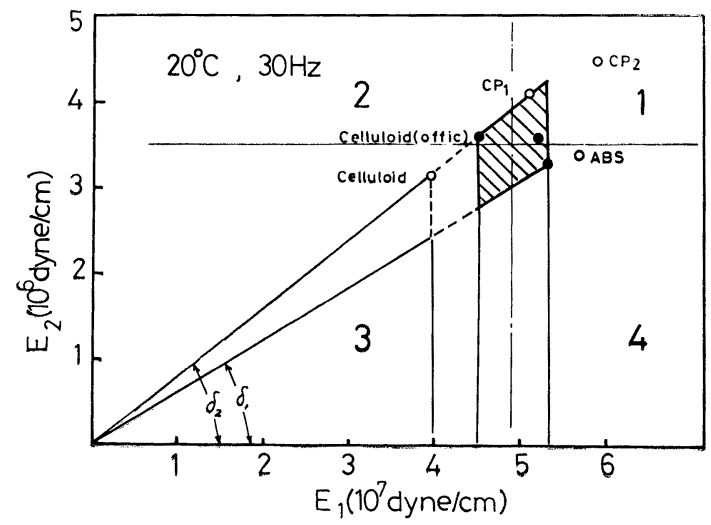

Fig. 8 Relation between the $E_{1}-E_{2}$ coordinate and

\begin{tabular}{|c|c|c|c|c|}
\hline \multirow[b]{2}{*}{ Ball } & \multicolumn{2}{|c|}{$20^{\circ} \mathrm{C}, \omega=1000 \mathrm{~Hz}$} & \multicolumn{2}{|c|}{$20^{\circ} \mathrm{C}, \omega=30 \mathrm{~Hz}$} \\
\hline & $\begin{array}{c}E_{1} \\
\left(\times 10^{7}\right. \\
\text { dyne } / \mathrm{cm})\end{array}$ & $\begin{array}{c}E_{2} \\
\left(\times 10^{6}\right. \\
\text { dyne } / \mathrm{cm})\end{array}$ & $\begin{array}{c}E_{1} \\
\left(\times 10^{7}\right. \\
\text { dyne } / \mathrm{cm})\end{array}$ & $\begin{array}{c}E_{2} \\
\left(\times 10^{6}\right. \\
\text { dyne } / \mathrm{cm})\end{array}$ \\
\hline $\begin{array}{l}\text { Celluloid, } 1 \\
\text { (official) }\end{array}$ & $\begin{array}{c}5.88 \\
\left(-15^{\circ} \mathrm{C},\right. \\
30 \mathrm{~Hz})\end{array}$ & $\mid \begin{array}{c}3.4 \\
\left(-15^{\circ} \mathrm{C},\right. \\
30 \mathrm{~Hz})\end{array}$ & 5.22 & 3.60 \\
\hline $\begin{array}{l}\text { Celluloid, } 2 \\
\text { (official) }\end{array}$ & $\begin{array}{c}6.05 \\
\left(-10^{\circ} \mathrm{C}, \mathrm{Hz}\right) \\
10 \mathrm{~Hz}\end{array}$ & - & 5.33 & 3.34 \\
\hline Celluloid, 3 & 5.22 & - & 4.50 & 3.60 \\
\hline $\mathrm{CP}-1$ & $\left(0^{\circ} \mathrm{C}, 20 \mathrm{~Hz}\right)$ & $\begin{array}{c}4.3 \\
\left(0^{\circ} \mathrm{C}, 20 \mathrm{~Hz}\right)\end{array}$ & 5.07 & 4.08 \\
\hline $\mathrm{CP}-2$ & 6.53 & - & 5.90 & 4.49 \\
\hline ABS & $\begin{array}{c}5.92 \\
\left(-15^{\circ} \mathrm{C}, \mathrm{Hz}\right) \\
10 \mathrm{~Hz}\end{array}$ & - & 5.65 & 3.44 \\
\hline Celluloid, 4 & 4.65 & - & 3.93 & 3.16 \\
\hline
\end{tabular}
the feeling quadrant.

Table I The feeling quadrant

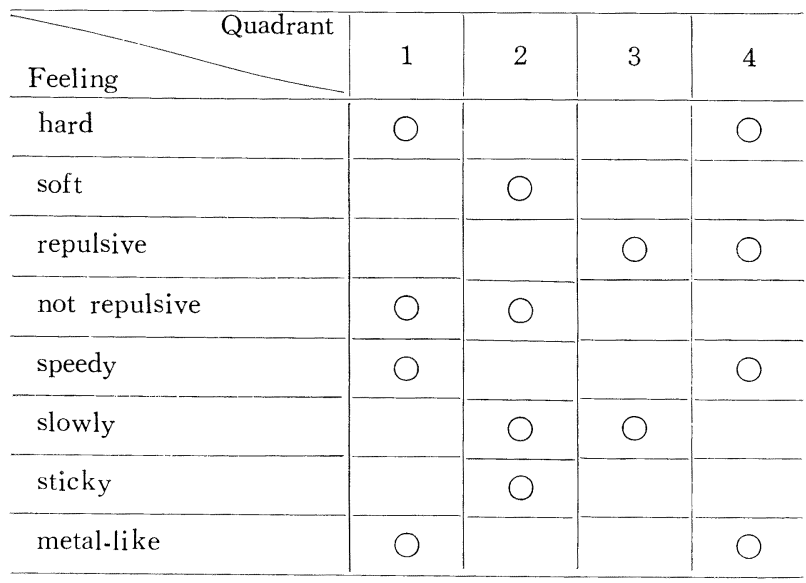

Table II The reduced dynamic stiffness of various ping-pong balls at the impact time 0.001 sec., $(, \quad)$ : reduced temperature and frequency

限は軟いが球離れが良く軽い感じ, 第 4 象限は硬く球離れも速く 金属的な感じ，という官能領域に分けられる。このような分類法 は一流プレイヤーによる各球の試し打ちの結果得られた打球感と も良い一致を示した (Table I). 
Table II はボールとラケットの実際の接触時間（約 $1 / 1000$ 秒） に対応するひずみ速度状態における各球の動的剛性を示す，時間 温度換算則は必ずしも成立しないボールがあったので，ボールの 変形，回復までに $1 / 1000$ 秒程度を要する温度，周波数に於ける 特性を参考までに示した。

\section{4. むす び}

以上の粘弾性試験機による卓球ボールの動的剛性の測定は, ボ ールと硬質アルミニウムの圧子で構成された測定系について行っ たものである．実際には硬質アルミニウムの代りにラバー張りの
ラケットが用いられるので, ボールの動的剛性と打球感との対応 は若干ずれるものと思わ机る。また，打球感を支配する因子とし て打球音が重要である。これについては打球音の周波数分析が有 力な方法であることが判明したので後日報告する。

\section{文}

\section{献}

1）ランダゥニリフシッッ, “弾性理論”(佐藤訳), p. 75 (1972) 東京図書.

2) Flügge, W., "Viscoelasticity", Chap. 3 (1975) Springer. 